\title{
Social Media: Factor Influencing Personal Transport for Leisure
}

\author{
Mohammad Zainul $^{1}$ and Zakky Zamrudi ${ }^{1} *$ \\ ${ }^{1}$ Islamic University of Kalimantan, Department of Management, Indonesia; Email: zainul@uniska- \\ bjm.ac.id,jzakky@gmail.com
}

\section{*Corresponding Author: Zakky Zamrudi}

\begin{abstract}
This paper is trying to examine the effect of social media in the use of personal transport for leisure purposes. Youngster are frequently identified as being adventurous and highly mobile, even few researcher modes of transportation choices play in important role in enhancing and fulfilling their desired experiences. In this paper, we would like to know the role of social media in enhancing the personal transport desire in south-east Kalimantan. Social media role is measured by borrowing the theory of technology acceptance model by using two variables namely perceived ease of use and perceived usefulness. A quantitative method was used to measure the variable by using questionnaire given to 230 respondents given to university student near south-east Kalimantan. The gathered data is analyzed by using generalized structured component analysis. The finding in this research indicates that both perceived ease of use and perceived usefulness of social media could affect individual intention to use personal transport. However, the larger effect has reflected by perceived usefulness. This means that social media has been recognized as a good reference to stimulate leisure by using personal transport.
\end{abstract}

Keywords: GSCA, TAM, personal transport, vacation, social media

\section{Introduction}

Personal transportation has becoming a major choice in Indonesia for decades. By 2017, there are about 113,030,258 motorcycle and 15,493,068 automobiles [1]. Indonesian society are likely to use personal transport rather than using public transportation were motivated by several aspects such as insufficient public transport facilities, limited range of public transport, prestige, flexibilities and many more.

The rise of technology has brought the ultimate change in information dissemination. The development of web 2.0 has brought the use of technology to society to interact each other. Social networking sites (SNS) or well-known as social media offered new ways to communicate among end users. People are becoming more than interconnected but rather becoming personal informant todays. Everyone can broadcast event that nearly happened. Not just a text or image, it offers sounds 
and video for to attract each other. Social media has become a powerful machine for promotion, including vacation/leisure. People tend to research their destination in social media after hear the information from people. The better information provided in the social media, the better they will visit those object [2].

Technology usability could be measured by using behavioral theories such as technology acceptance model and theory of reasoned action etc. Technology acceptance model has been used for decades to measure ones intention to use particular systems to fulfill their necessities [3]. TAM consist of perceived ease of use that reflect the ones perception against the systems navigation procedure. Do the systems offer a rather difficult to understand or in the contrary in provide a well organized navigation and painless interface [4,5]. The other constructs was the perceived usefulness which reflect the degree of information validity provided inside the systems [6]. As the previous research has revealed, the better perception of user on the system is corresponding to the higher usefulness perception [6].

Current research proposed that independent tourist tend to use personal transport rather than using public transport. In most of developed countries such as Norway public transportation is being avoided due to its lack of flexibility [7]. Most of the independent traveler was using train and bus. The finding is rather interesting which the personal transport may create a higher cost rather than using personal transport but it is in trend nowadays [8]. Thus, this research proposes the role of social media as a personal reference for personal transport.

\section{Data and Methods}

This study categorized as a cross-sectional study which used the explanatory approach by quantitative in nature. The purpose of the study was to predict the most considerable factor in reflecting the intention to use personal transport in visiting the tourist object among youngsters near South East Kalimantan, Indonesia.

\subsection{Instrument Development}

This research has built by using three constructs namely perceived ease of use, perceived usefulness, and intention to transport personally. The questionnaires developed from construct consist of 15 questions formulated from various related studies. The questionnaire was measured by using 7 scale semantic differentials to provide wider range of answers. By using a larger span of answer choices, hopefully it would able to explain the data comprehensively $[9,10]$. 


\subsection{Data Collection}

The data was collected through a survey conducted in the south-east Kalimantan province Indonesia during December 2018 to January 2019. Pilot studies were developed involving 30 respondents were conducted to ensure the wording and sentences were clearly. Usable data of 230 responses were collected from university student around Banjarbaru, Banjarmasin and Kabupaten Banjar, South East Kalimantan Province, Indonesia. The sample amount was defined by using prior research correlation due to unknown population by using iteration method [11]. The sample was drawn by using purposive sample. The criteria of respondent should be an active user of social media including Instagram, Facebook, and Twitter.

\subsection{Data Analysis}

The data was analyzed by using the Generalized Structured Component Analysis (GSCA) by the help of GesCA software. The method was employed due to the research purposes to explore the related model while ensuring the model consistency [12]. GSCA was the great alternative between the Covariance Based SEM (CB-SEM) with its ability to measure degree of model consistency (parametric capability) and Partial Least Square based SEM (PLS-SEM) with its ability to create a non-parametric capability for model assessment $[13,14]$. Thus this research was used GSCA as the alternative for both SEM modelling or called as semi-parametric SEM analysis. The steps on GSCA were including construct development, data gathering, model fit evaluation, outer model description, inner model (path analysis) amongst construct, and results discussions.

\section{Results}

The data gathered from the field shows 230 usable data. Then, the data is analyzed by using Generalized Structured Component Analysis (GSCA). According to the FIT and AFIT criteria, the proposed model is able to explain the variance for 0.657 and 0.654 (see Table 1). This number indicates that the construct are able to reflect the model for $65 \%$ while the rest $35 \%$ are explained by another variable.

Table 1 Model FIT evaluation. Source: [14]

\begin{tabular}{cc}
\hline \multicolumn{2}{c}{ Model Fit } \\
\hline FIT & 0,657 \\
\hline AFIT & 0,654 \\
\hline GFI & 0,997 \\
\hline SRMR & 0,062 \\
\hline
\end{tabular}


The unweighted least square indicates by GFI and SRMR also shows a good results shows by the GFI 0,997 (closer to 1 is better) and SRMR 0,062 (closer to 0 is better). Based on this result, the proposed model is considered have met the good FIT criteria.

Parameter estimates shows the variance explained by items which exhibit the most important items corresponds the latent variable. In the Table 2 below, the variance is indicating by the AVE value which reflect the validity measurement. Based on the table 2 below, all of the variable has met the validity cut-off value which the required value has to be more than 0.5 (AVE > 0.5). The reliability analysis was reflected from the alpha number indicates in table 2 below. The required cutoff for the reliability analysis was 0.688 (Cronbach alpha > 0.688). From the table 2 below it shows that all of the variable has met the reliability cut-off value. Thus the construct built for this research has met the internal consistency.

The loading factor for each items are shown in the Table 2 below. The most considerable items in variable perceived ease of use were indicates by items PEOU5 shows estimates value of 0.8543 and se $=0.0253$. The most considerable items in variable perceived usefulness indicates by item PU4 shows estimates value of 0.905 and $\mathrm{se}=0.0178$. The most considerable items in variable intention to use personal transport shows estimates value of 0.8891 and se $=0.0222$ (see also Fig. 1).

Table 2 Parameter estimates. Source: [14]

\begin{tabular}{|c|c|c|c|c|}
\hline \multirow{2}{*}{$\begin{array}{c}\text { Variable/ } \\
\text { Items }\end{array}$} & \multicolumn{2}{|c|}{ Loading } & \multirow[b]{2}{*}{ AVE } & \multirow[b]{2}{*}{ ALPHA } \\
\hline & Estimate & SE & & \\
\hline \multicolumn{3}{|c|}{ Perceived Ease Of Use } & 0.652 & 0.839 \\
\hline PEOU1 & 0.7149 & 0.0438 & & \\
\hline PEOU2 & 0.7999 & 0.0534 & & \\
\hline PEOU3 & 0.8291 & 0.0305 & & \\
\hline PEOU4 & 0.8486 & 0.0280 & & \\
\hline PEOU5 & 0.8543 & 0.0253 & & \\
\hline PEOU6 & 0.7892 & 0.0373 & & \\
\hline \multicolumn{3}{|c|}{ Perceived Usefulness } & 0.763 & 0.922 \\
\hline PU1 & 0.8502 & 0.0183 & & \\
\hline PU2 & 0.8873 & 0.0127 & & \\
\hline PU3 & 0.8796 & 0.0184 & & \\
\hline PU4 & 0.905 & 0.0178 & & \\
\hline PU5 & 0.8432 & 0.045 & & \\
\hline \multicolumn{3}{|c|}{ Intention to travel visit } & 0.754 & 0.892 \\
\hline IPT1 & 0.8433 & 0.042 & & \\
\hline IPT2 & 0.8787 & 0.0168 & & \\
\hline IPT3 & 0.8607 & 0.0234 & & \\
\hline IPT4 & 0.8891 & 0.0222 & & \\
\hline
\end{tabular}




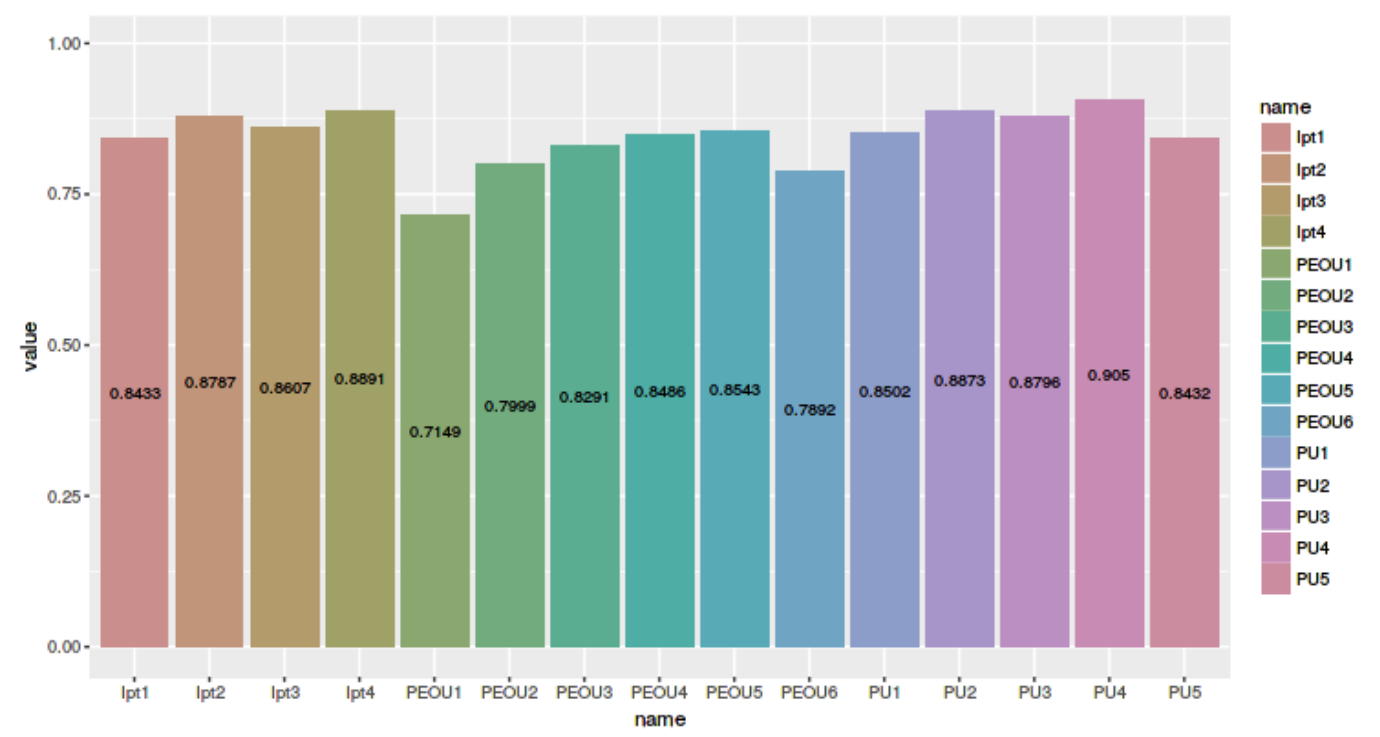

Fig. 1 Loading factor plots diagrams. Source: [14]

Figure 2 below indicates the direct effect of endogen latent variable on exogenous latent variable. This validated model shows that perceived ease of use and perceived usefulness of social media shows a significant effect in increase the intention to use personal transportation in reaching local tourist object.

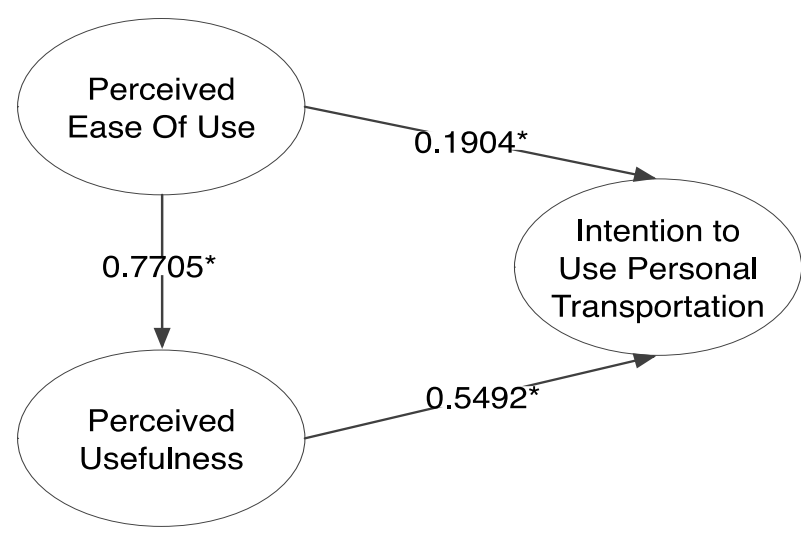

Fig. 2 UTAUT Inner model evaluation. Source: [14]

The largest estimates path coefficient was shown by the perceived usefulness rather than the perceived ease of use. However, the indirect effect is shown in the Table 4 below indicates that perceived ease of use mediated by perceived usefulness has a larger effect than the direct effect $(0.4231>0.1904)$. The direct effect is shown in the Table 3.

Table 3 Direct effect. Source: [14]

\begin{tabular}{lrcc}
\hline \multicolumn{4}{c}{ Direct Path Coefficients } \\
\hline & Estimate & SE & CR \\
\hline PEOU->ITT & 0.1904 & 0.0930 & 21.1096 \\
\hline PEOU->PU & 0.7705 & 0.0365 & 2.0473 \\
\hline PU->IPT & 0.5492 & 0.0981 & 5.5984 \\
\hline
\end{tabular}


Table 4 Indirect effect. Source: [14]

\begin{tabular}{lrrr}
\hline \multicolumn{4}{c}{ Indirect Path Coefficients } \\
& Estimate & SE & CR \\
\hline PEOU->PU->IPT & 0.4231 & 0.086 & 5.0244 \\
\hline
\end{tabular}

\section{Discussion}

Technological development has brightening the world brought by the internet development, which start by the emergence of web 2.0. Web 2.0 defined as a supportive platform, which enable the societies to take an active role working on the internet which one of them was the social media. Personal transport has been becoming part of Indonesian history for centuries. Youngsters have recognized to have a higher desire in traveling becoming main contributors of social media users and developers. The use of social media is becoming a powerful tool to measure present trends of modern societies. Tourism object is currently in vast development start from natural attraction to modern amusement park. The use of social media has predicted to be the successor to this condition. The finding proposed above indicates that perceived usefulness of social media shows a larger number in estimates rather than perceived ease of use. It means that the social media has recognized as a useful tool for young traveler to find related information about the travel object. This result was in line with the hypothesis testing that indicates the perceived usefulness has shown a higher estimates value rather than the perceived ease of use. The lower estimates value by perceived ease of use doesn't mean that the systems were difficult to be understood. Otherwise, social media has been well understood by the youngsters, which means that they are quite familiar with social media.

This research suggests that this finding become an interesting point for government as a regulator in promoting local tourism object particularly the one that managed by surrounding communities. This finding also becoming a good sign for travel business in creating a great leisure package that offer individual travel that is not only customizable but also cheap.

\section{Conclusion}

This study investigates the role of social media in accommodating the personal transport for leisure purposes. The study involved three variables derived from multi discipline that mainly taken from behavioral theory. This research borrows the theory of Technology Acceptance Model by using two exogenous variable namely perceived ease of use and perceived usefulness. The endogenous variable was the intention to use personal travel for leisure. The study indicates that the larger effect of social media experience shows by perceived usefulness. The effect of perceived ease of use may resulting a low value since the social media is quite familiar for youngsters. Youngsters tend to use social media on their daily basis. Thus it explains why the indirect effect of perceived ease of use of 
social media on intention to use personal travel for leisure is larger than the direct effect. The familiarity on social media use, create such a perception on the usefulness in providing sourceful information.

Limitation in this study was the limited amount of supportive literature in analyzing the tourism object in the field of transportation particularly that related to the personal transportation among youngsters. The future research would be better if there are more variables involved in the model such as social media experience.

\section{Acknowledgments}

This works was fully supported by Islamic University of Kalimantan supervised by Center of Research, Research and Community Services Bureau. A higher gratitude is given to the student involved in this research for relentless support in data managing, sorting, and up to research report development.

\section{References}

[1] Badan pusat statistik. (2018). Perkembangan Jumlah Kendaraan Bermotor Menurut Jenis, 1949-2017. Badan Pusat Statistik. Retrieved February 24, 2019, from https://www.bps.go.id/linkTableDinamis/view/id/1133.

[2] Parra-López, E., Bulchand-Gidumal, J., Gutiérrez-Taño, D. \& Díaz-Armas, R. (2011). Intentions to use social media in organizing and taking vacation trips. Comput. Human Behav. $27(2), 640-654$.

[3] Ayeh, J.K., Au, N. \& Law, R. (2013). Predicting the intention to use consumer-generated media for travel planning. Tour. Manag., 35, 132-143.

[4] Renny, Guritno, S. \& Siringoringo, H. (2013). Perceived Usefulness, Ease of Use, and Attitude Towards Online Shopping Usefulness Towards Online Airlines Ticket Purchase. Procedia - Soc. Behav. Sci. 81, 212-216.

[5] Kassim, E.S., Azman, A.M., Othman, A.K. \& Zamzuri, N.H. (2017). "Perceived usefulness, perceived ease of use and perceived risks of social commerce intention among youths. In Proceedings of the 29th International Business Information Management Association Conference - Education Excellence and Innovation Management through Vision 2020: From Regional Development Sustainability to Global Economic Growth, 2017. 
[6] Chooprayoon, V., Fung, C.C. \& Depickere, A.A. (2007). TECTAM, a modified technology acceptance model to assess E-commerce technologies adoption by Thai SME. In IEEE Region 10 Annual International Conference, Proceedings/TENCON.

[7] Butler, G. \& Hannam, K. (2012). Independent tourist's automobilities in Norway. J. Tour. Cult. Chang. 10(4), 285-300.

[8] Hussain, R., Al Nasser, A. \& Hussain, Y.K. (2015). Service quality and customer satisfaction of a UAE-based airline: An empirical investigation. J. Air Transp. Manag. 42, 167-175.

[9] Abdurrahim, A. \& Zakky, Z. (2018). Wisatawan digital peran media sosial dalam membentuk minat berwisata. At-Tadbir J. Ilm. Manaj. 2(2).

[10] Zakky, Z. \& Teguh, W. (2018). Promoting the Use of Social Commerce on SME in the Context of Logistics: UTAUT Model Examination. LOGI - Sci. J. Transp. Logist. 9(2), 7382.

[11] Machin, D., Campbell, M. J., Tan, S. B. \& Tan, S.H. (2009). Sample Size Tables for Clinical Studies: Third Edition.

[12] Montreal, H. \& Takane, Y. (2004). Generalized structured component analysis heungsun Hwang.

[13] Jung, K., Takane, Y., Hwang, H. \& Woodward, T.S. (2012). Dynamic GSCA (Generalized Structured Component Analysis) with Applications to the Analysis of Effective Connectivity in Functional Neuroimaging Data. Psychometrika. 77(4), 827-848.

[14] Hee Jung, K. (2011). Dynamic GSCA (Generalized Structured Component Analysis): A Structural Equation Model for Analyzing Effective Connectivity in Functional Neuroimaging. 